\title{
Research in graphic design
}

\author{
Article
}

Accepted Version

Walker, S. (2017) Research in graphic design. The Design Journal, 20 (5). pp. 549-559. ISSN 1460-6925 doi: https://doi.org/10.1080/14606925.2017.1347416 Available at https://centaur.reading.ac.uk/71369/

It is advisable to refer to the publisher's version if you intend to cite from the work. See Guidance on citing.

To link to this article DOI: http://dx.doi.org/10.1080/14606925.2017.1347416

Publisher: Taylor \& Francis

All outputs in CentAUR are protected by Intellectual Property Rights law, including copyright law. Copyright and IPR is retained by the creators or other copyright holders. Terms and conditions for use of this material are defined in the End User Agreement.

\section{www.reading.ac.uk/centaur}

\section{CentAUR}

Central Archive at the University of Reading

Reading's research outputs online 


\section{Research in graphic design}

Even though design research has gained momentum and respect within the academic community over the last 20 years or so, research in graphic design has not been regarded as a significant player. Indeed, there has been a tendency, even within the design community, to regard graphic design as something that is supplementary or additional to other projects. This is not helped by the occasional association of the term 'graphic design' with not particularly thoughtful, aestheticled design decision making. In this paper, a more positive view of graphic design research is proposed, one that identifies a varied and distinctive field of research.

First, what is graphic design? Graphic designers try to illuminate or explain things using graphic language, which may be verbal, pictorial or schematic, and presented on paper or screen. Graphic designers work with illustrators, photographers, coders, editors, writers and others involved in the graphic presentation of language. And, as with all designing, it is a planning and problemsolving discipline, concerned with purpose, process, visual judgement, engagement with users and circumstances of use.

But graphic design, and certainly graphic design research, is about more that than the work produced by a 'graphic designer', a form of professional practice with the reality of variable quality. A broad definition is certainly helpful in thinking about 'graphic design research', not least because it embraces what might be called sub-disciplines, for example, typography, wayfinding, book \& periodical design, interaction design, illustration, exhibition design, branding and corporate identity. And within each of these areas there are strands of research activity around people, locations, history, effectiveness, theoretical approaches and the role of graphic design in broader cultural movements. Form many the term 'communication design' is synonymous with 'graphic design'.

Graphic design - perhaps because of the nomenclature issues mentioned above - tends not have a high profile within design research. Indeed, in the Research Excellence Framework 2014: Overview report by Main Panel D and Sub-panels 27 to 36 (HEFCE 2014: 85), the feedback was that 'While there were high quality exceptions, the intellectual and theoretical underpinning of graphic and communication design was thought to be generally weak'. However, graphic design research can also be labelled as design history, exhibition design, critical writing, and it is often a constituent of practice-based research in inter-disciplinary projects relevant to health, education and business process - each of these identified as areas of strength the REF Overview Report.

A challenge for graphic design researchers is to raise its profile within projects described as service design, information design, experiential design - terms often associated with large-scale research projects to improve well-being, interaction with space, or to elucidate process. There is 
often a role for graphic design in paper and digital form but it is sometimes regarded as the kind of design that is additional rather than an integral constituent of a larger-scale project. Graphic design research is often key to provide different kinds of evidence of the way that design decisions are made, of the way that graphic devices are used, interpreted and situated.

There is a strong historical dimension to graphic design research: studies about people or movements, associated with particular locations. Such research thrives on archival work and its established methods of close reading, analysis, comparison, synthesis and curation. Collections and archives have inspired research outputs in the form of monographs, journal articles, exhibitions, databases and digital resources that have raised the profile of graphic design heritage. This has been reinforced by the development of graphic design archives, such as those at the universities of Brighton and Reading in the UK, the University of Amsterdam, and in the US, Rochester Institute of Technology. [1] [2]

Graphic design research excellence resides in monographs and articles about individuals who have made a contribution to the field. The most authoritative and useful accounts derive from careful and rigorous archival work paying attention to the deliberations and processes of design and production, and to correspondence, notebooks and other ephemeral material that sets the context for the work that is produced, and the networks involved in its making. Examples here include Christopher Burke's work on Jan Tschichold (2008) and Markus Rathgeb's on Otl Aicher (2006), which developed from their PhD research; Frederike Huygen's (2014) book about the Dutch designer Juriaan Schrofer and Christioher Wilson's eagerly awaited book about Richard Hollis (2017 in press).

Some researchers deal with bodies of work, or approaches to designing - perhaps related to particular individuals, to national styles, or to social and historical trends. The 'Isotype revisited project', with numerous research outputs, has renewed interest in the work of Otto and Marie Neurath (see Burke, Kindel \& Walker 2013). Richard Hollis's book Swiss graphic design (2006) exemplifies authoritative text and illustrations as a result of serious investigation. Modern typography in Britain: graphic design, politics and society, (Typography Papers 8), presents essays and shorter articles about graphic design in Britain from the end of the Second World War to the early 1970 s that 'fizz with provocative interconnections: between print culture, photojournalism and publishing, the London of émigrés, political meetings and demonstrations, cultural cafés and art schools' (Stiff 2009). Here we see graphic design research at its best and that evokes its alignment with other discipline areas. [3]

Some researchers engage with sets of graphic artefacts, over time or in particular contexts. Stephen Boyd Davis studies the historical representation of time and associates this with interactive digital media, a distinctive and rich research area that has stimulated work by $\mathrm{PhD}$ 
students (see, for example, Boyd Davis \& Krautli 2015). Runs of journals and magazines with strong and distinctive graphic design have attracted attention, such as Rick Poyner's review of Typographica (2001) and Eric Kindel's work on Future and Fortune magazines (2017). Graphic design research is sometimes subsumed within studies described as 'cultural history' or 'visual culture' - nomenclature again getting in the way. A thorough study of Olympic games posters, for example, would be likely to include Margaret Timmers's highly visual account (2008), but the prominence of such posters has attracted interest from cultural historians as well, for example, John Houghson's (unillustrated) paper about the cultural legacy of Olympic posters in the journal Sport in Society (2010). Posters are a popular theme for research: The Poster: Art, Advertising, Design, and Collecting, 186os-19oos by Ruth E. Iskin covers different perspectives on posters, including a stimulating chapter on poster design: 'the dialogues of image and word', situating design within a broader context.

Iskin also devotes a chapter to the methods by which posters in the nineteenth century are produced, and is a reminder that graphic design research includes the technology and the role it plays in enabling creativity and dissemination. Research in printing history and print techniques crosses a number of sub-disciplines - including printing history, history of the book and of publishing, which is why it may be overlooked as research in graphic design. Michael Twyman's magnum opus on chromolithography (2013), a process that has many applications, is broad in scope, based on rigorous archival research supplemented by his experience of printing from lithographic stones. Other studies may be more focused on a particular process and its usage, an example here being Roderick Cave's book about nature printing (2010). Thinking about printing and making has inspired innovative research methods in the form of reconstruction: using notebooks, drawings, prints and plans for the past to produce replica machines and devices to investigate the production of materials in the past (see Kindel 2013), which has informed historic and contemporary work on printing with stencils. Technology revivals. such as letterpress printing and new technologies including 3-D printing offer new research possibilities, such as those being explored by the Centre for Fine Print Research at the University of the West of England. Digital technologies inform research in data visualization and information design, for example, Ian Gwilt's work (2015) on transforming digital data into accessible material forms. [4]

Gwilt's work builds on the tradition of graphic communication in public service: forms, posters and instructional text related to health, education and the everyday business of government. Working out the optimal effectiveness of such artefacts for different user groups is where there is an established graphic design research tradition, as seen in recent edited volumes about information design by Jorge Frascara (2015), and Black, Luna, Lund \& Walker (2017). The papers in these volumes reflect graphic design history, theory and practice - the latter embedded though co-design and participatory design methods. Information design for health is one 
example where the design and evaluation of artefacts with a particular purpose for a particular audience is one way that graphic design practice as research is developed and applied. There are examples in Tsekleves \& Cooper (2017) in chapters by Alison Black about the design of supporting materials for acute kidney disease treatment, and Karel van der Waarde, who analyses the graphic presentation of information on ibuprofen packaging with reference to older people. [5]

Within what I have earlier referred as sub-disciplines of graphic design, such as typography and typeface design, there is considerable focused and specialist research. Sophie Beier's highlyvisual Reading letters: designing for legibility, deriving from $\mathrm{PhD}$ research, synthesises material from typeface history, psychology and type design. Dyson \& Suen in Digital fonts and reading (World Scientific 2016) offer perspectives about 'design for reading' from science and design researchers and practitioners, and reinforces cross-disciplinarity. These are just two examples of work that is often represented in the journals mentioned below, and that draw attention to a rich seam of research, with well-established quantitative and qualitative methods. Indeed, it is at the cross-disciplinary intersection that graphic design theory flourishes. Technical communication and applied linguistics are closely related to the graphic presentation of language. As examples, Charles Kostelnick (2003) focuses on visual language in professional communication and John Bateman (2014) on the dynamic between text and pictures. Both introduce ways of looking at the rhetorical structure and use of graphic and typographic conventions in graphic communication. Joanna Drucker's Graphesis: visual forms of knowledge production (2014), also a crossdisciplinary study, is an important contribution to theory in graphic design research, especially as it is focused on digital media. Such works adds to the theoretical infrastructure for communication design research, and in turn reinforces its cross-disciplinary potential.

The 'anthology' or 'reader' is a well-established format for books about graphic design gatherings-together of material from a particular time that offer new ideas, or raise the profile of forgotten endeavours. In this context, the research lies in the curation, perhaps the discovery, along with analytical and contextual narrative. Such accounts help to scope out and define the field and sit within a publishing genre that is well established within design as a whole, recently described as 'a gathering of flowers' by Grace Lees Maffei and Daniel Huppatz in this journal (2017). Examples here would be Helen Armstrong's Graphic design theory: readings from the field (New York: Princeton Architectural Press 2009); Gerda Breuer and Julia Meer's Women in graphic design Berlin: Jovis Verlag 2012 and, most likely, Teal Trigg's forthcoming Graphic design reader (London: Bloomsbury 2018.

And what of graphic design practice as research? Rathna Ramanathan and Fiona Ross's work on book and typeface design for the Murty library is an excellent example drawing together cultural and historical precedent to inform contemporary graphic design (Ross 2015). In REF 2014 there 
were strong practice-based research outputs in type design, book design, illustration and photography, each enhanced by supporting materials that articulated process and exploration to validate the research. Practice also contributes to research that is concerned with identifying the most appropriate graphic form (relative to a particular context and set of circumstances), of an icon, pictogram or symbol; or a typeface that benefit a particular kind of reader.

One of the challenges for graphic design researchers is publication, not least because of the likelihood that many illustrations will be needed which often incur costs for permission to reproduce. Relevant journals may limit the number of illustrations that can be used or be printed in black only. There are relatively few graphic design academic journals that researchers turn to, perhaps Communication Design (Taylor \& Francis), Journal of Design History (OUP), Information Design Journal (Benjamins), and Visible Language (University of Cincinnati) but for many these lack the production values that many graphic design researchers would like to see. The relatively new Journal of Illustration (Intellect) perhaps offers potential for publication of papers that are about the use of illustration in designed objects. Several researchers turn to Eye magazine and Baseline to publish their work, even though these are geared towards nonacademic audiences, because they can be assured of the high quality of the illustrations. Such publications raise the profile and extend the reach of the work even though they may not feature in research assessment exercises. Typography papers, launched in 1996, set out to publish 'new papers on typography and graphic communication, and also papers at the meeting places between typography and other disciplines' and aimed to ensure quality editorial, design and production standards welcoming highly-illustrated papers, with some facility for colour. This series - of 9 book-length journals - has enabled and ensured the publication of research papers that may have floundered in more traditional academic publications routes. Hyphen Press, latterly Typography Papers' publisher, is renowned for its high-quality standards and this has resulted in the initiation and publication of some fine graphic design research in the form of books on Anthony Froshaug, Karel Martens and Edward Wright, and by authors including Robin Kinross, Fred Smeijers, Tanya Harrod and Stuart Bailey. Publishers, such as Unit Editions and Lars Müller with their accessible, well-printed compilations of the work of graphic design practitioners and facsimile editions of key graphic design texts, draw attention to the work, and serve to encourage questions about the making, the inspiration, the reception of the material which can spawn research.

I would argue that graphic design research, using the broad definition offered here, is wellestablished with much original, significant and rigorous research, whether history, theory or practice. There remains considerable potential for the development of methods and frameworks for considering graphic design, to contribute new knowledge and understanding about materiality, making and relationship to broader social, political, cultural and economic contexts, whether the work of particular designers or groups of designers, or sets of object types, or of 
schematic presentations of data and information and beyond. Graphic design research - I would prefer the term 'communication design' - is thriving, if you know where to look.

Bateman, J. A. (2014). Text and image: a critical introduction to the visual-verbal divide. Abingdon: Routledge, Taylor \& Francis Group.

Black, A., P. Luna, O. Lund, \& S. Walker (eds). 2017. Information design: research and practice, Abingdon: Routledge.

Boyd Davis, S. \& F. Kräutli (2015). The idea and image of historical time: interactions between design and digital humanities. Visible Language, 49/3, 101-119

Burke, C. (1998). Paul Renner: The art of typography. London: Hyphen.

Burke, C., E. Kindel, \& S. Walker (eds). (2013). Isotype: Design and contexts, 1925-1971. London: Hyphen.

Cave, R. (2010) Impressions of nature: a history of nature printing. London: British Library.

Frascara, J. (ed). (2015). Information design as principled action: making information accessible, relevant, understandable, and usable. Champaign, Illinois: Common Ground Publishing.

Gwilt, I. (2015). Big data - small world: materializing digital information for discourse and cognition. In: Harrison, D. (ed.) Handbook of Research on Digital Media and Creative Technologies. Hershey, Pennsylvania, IGI Global, 33-46.

HEFCE (2014). Research Excellence Framework 2014: Overview report by Main Panel D and Sub-panels 27 to 36. London: HEFCE.

Hollis, Richard. (2006). Swiss graphic design: The origins and growth of an international style, 1920-1965. London: Laurence King.

Hughson, J. (2010) The cultural legacy of Olympic posters, Sport in Society, 13:5, 749-759

Huygen, F. 2014. Jurriaan Schrofer: graphic designer, pioneer of photo books, art director, teacher, art manager, environmental artist. Valiz, Amsterdam.

Kindel, E. (2013). A re-construction of stenciling based on the description by Gilles Filleau des Billettes. Typography Papers 9, London: Hyphen Press, 28-65.

Kindel, E. (2017) Future, Fortune, and the graphic design of information. In Black, A., Luna, P. Lund, O. and Walker, S. (eds). Information design: research and practice, Abingdon: Routledge.

Kostelnick, C. \& M. Hassett. (2003). Shaping information: the rhetoric of visual conventions. Carbondale, Ill.: Southern Illinois University Press.

Lees-Maffei, G. \& D. Huppatz, (2017). A Gathering of Flowers: On Design Anthologies. The Design Journal, 1-15.

Poynor, R. (2001). Typographica. London: Laurence King.

Rathgeb, M. (2006). Otl Aicher. London: Phaidon.

Ross, F. (2015) The Murty Classical Library of India - a collaborative design project for Harvard University Press. In: Kudrnovska, L. (ed.) 365 Typo. Étapes, Paris, pp. 258-259. 
Stiff, P. ed, (2009). Modern typography in Britain: graphic design, politics and society, Typography Papers 8, London: Hyphen.

Timmers, M. (2008). A century of Olympic posters. London: V\&A/

Tsekleves, E. \& R. Cooper (eds). 2017. Design for Healthcare, London: Routledge

Twyman, M. (2013). A history of chromolithography: printed colour for all. London: British Library; New Castle, DE: Oak Knoll Press

Wilson, C. (2017 in press). Richard Hollis designs for the Whitechapel: a graphic designer and an art gallery at work in twentieth-century London. London: Hyphen 


\section{Captions}

[1]

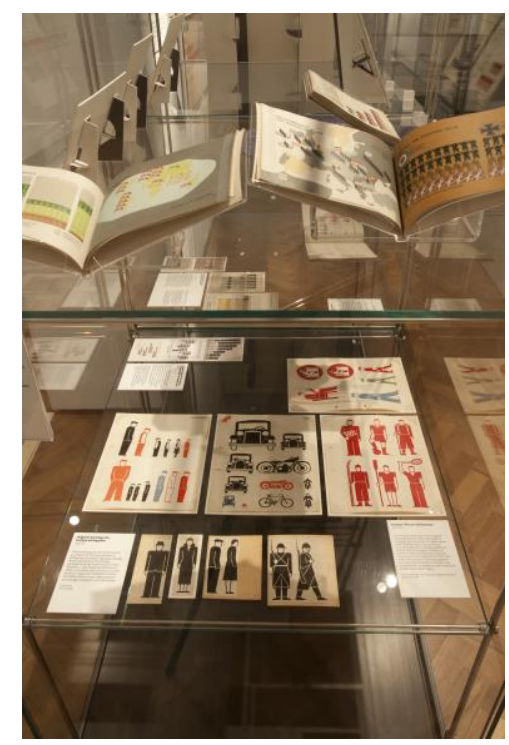

Collections and archives are the foundation of much graphic design research. This image shows material from the Otto and Marie Neurath Isotype Collection, University of Reading, on display at a curated and designed exhibition Isotype: international picture language a collaboration between 'Isotype revisited' and the V\&A in 2010/11. Photograph: Isotype revisited / Laura Bennetto.

[2]

Image from Dropbox supplied by Brighton

Student volunteer Suzy Lorton surface cleaning a poster by Macdonald Gill in the University of Brighton Design Archives. Photograph: Sirpa Kutilainen. 


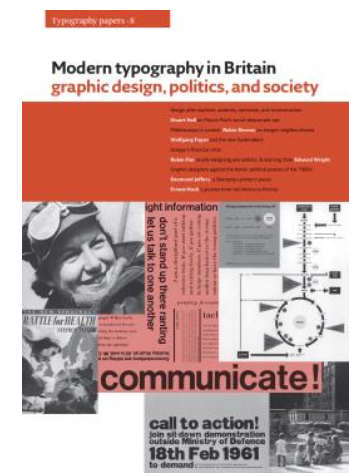

Modern typography in Britain: graphic design, politics and society (Hyphen, 2009), edited by Paul Stiff and published by Hyphen Press, exemplifies excellent graphic design research. It includes papers by Stuart Hall, David Lambert, Sally Jeffery, Ian McLaren and Petra Černe Oven.

\section{$[4]$}

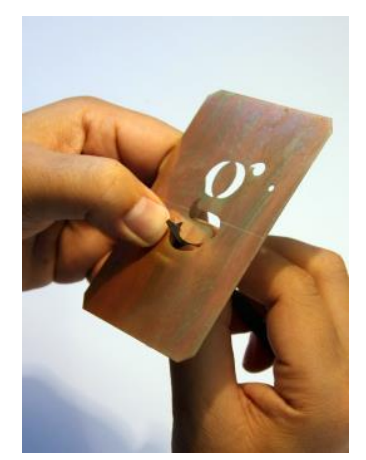

Research into stencilled texts and books has involved collaborations between Eric Kindel and Fred Smeijers. This image shows the reconstruction of postulated stencil-making methods used in France in the eighteenth century. Smeijers has etched the letter ' $\mathrm{g}$ ' from a thin brass plate and is refining its shape with a file. Photograph: Eric Kindel

[5]

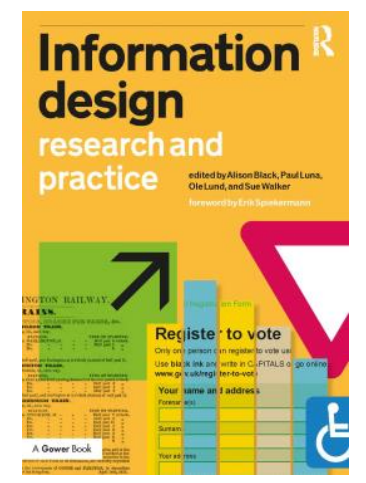

Graphic design research often features under alternative descriptions of design. Information design: research and practice (Routledge, 2017), for example, contains numerous chapters on history, theory and practice of graphic communication. 
